\title{
Immunoglobulin-Mediated Cell Signaling
}

National Cancer Institute

\section{Source}

National Cancer Institute. Immunoglobulin-Mediated Cell Signaling. NCI Thesaurus. Code C19952.

A process that involves the binding of an immunoglobulin on the surface of a B cell to a cognate antigen on the surface of a follicular dendritic cell, resulting in a strong survival signal for the immunog lobulin-bearing cell. These interactions are involved in activation, proliferation and maturation of selected B cells and apoptosis of non-selected populations. 